\title{
MIMR THE DIFFERENCES IN THE EFFECTIVENESS OF PROVIDING THICK BLANKETS AND ELECTRIC BLANKETS WITH REDUCING SHIVERING INCIDENCE ON POSTOPERATIVE PATIENTS IN SURGICAL INSTALLATIONS DR. SITANALA HOSPITAL TANGERANG IN 2019
}

\author{
Dewi Fitriani ${ }^{1}$, Rita Dwi Pratiwi ${ }^{1 *}$, Gita Ayuningtyas ${ }^{1}$, Sri Murtiningsih¹, Sandeep Poddar ${ }^{2}$ \\ ${ }^{1}$ Widya Dharma Husada Tangerang School of Health Science, Indonesia \\ ${ }^{2}$ Lincoln University College, Malaysia \\ *Corresponding Author's Email: ritadwipratiwi@wdh.ac.id
}

\begin{abstract}
Introduction: Post Anesthetic Shivering (PAS) or the incidence of post-anesthetic shivering is reported to be around $33-65 \%$ in patients undergoing general anesthesia and about $33-56,7 \%$ in patients undergoing spinal anesthesia. The treatment can be done pharmacologically with drugs and non-pharmacologically one of them with a warm blanket. The purpose of this study was to determine the differences in the effectiveness of giving thick cloth blankets and 380C electric blankets with a reduction in the incidence of shivering in postoperative patients at the Surgical Installation dr. Sitanala Tangerang Hospital. Method: The research method was a quantitative study with a quasi-experimental design with a pre-test post-test with control group design. The number of samples were 30 patients. Data was collected by observing shivering responses. The intervention was carried out by firing 380C electric blankets and thick cloth blankets. Result: The results showed that of the 15 postoperative patients before being given an electric blanket, almost half were 7 (46.7\%) having grade 3 shivering, where as in patients given thick cloth blankets almost half were $6(40 \%)$ having grade 2 shivering. Electrical heating is almost half that is $6(40 \%)$ does not experience shivering (grade 0 ), where as in patients given regular blankets almost half are $6(40 \%)$ experiencing grade 2 shivering. Statistical test results were obtained ( $p$-value $=0.001, \alpha: 0.05)$ and ( $p$-value $=0.005, \alpha: 0.05)$. Conclusion: there was an electric warm blanket or thick cloth blanket that influences the incidence of shivering in postoperative patients at the Surgical Installation dr. Sitanala Tangerang Hospital, but electric blankets are more effective than thick blankets. Suggestion is that the hospital is expected to make an intervention to provide electric warm blankets with a temperature of $380 \mathrm{C}$ postoperatively can be used as a fixed procedure for the service of surgical patients to prevent complications of shivering.
\end{abstract}

\section{Keywords: Thick Blanket; Electric Blanket; Shivering Incidence}

\section{INTRODUCTION}

Hypothermia is a state of core body temperature below $36^{\circ} \mathrm{C}$ (normothermic: $36.6^{\circ} \mathrm{C}-37.5^{\circ} \mathrm{C}$ ) (Guyton \& Hall, 2014). Hypothermia is a medical emergency that can arise when the body loses heat faster than heat production. When the body temperature drops, the nervous system and other organs cannot work normally. If it is not followed up, hypothermia can eventually lead to heart and respiratory system failure, and even death (Suindrayasa, 2017).

Overcoming hypothermia during and after anesthesia is an important part, given the various problems that can be caused as previously mentioned. In general, the management of shivering is divided into two, namely non-pharmacotherapy and pharmacotherapy (Fatoni, Isngadi, \& Jaya, 2014 \& Koeshardiandi, 2011).

Efforts to overcome the shivering effects of postoperative hypothermia, by means of pharmacotherapy include drugs, both opioid and non-opioid which have been tested to treat postoperative hypothermia such as pethidine, tramadol, clonidine, and meperidine. Giving drugs certainly causes side effects in the form of nausea, vomiting and respiratory depression. Non-pharmacotherapy includes various mechanical interventions such as warm intravenous fluids, heating lamps, warming blankets, heating mattresses, warm humidifiers and increased room temperature, pressurized heating systems, electric mattresses and blankets, and water mattress and covers (Horosz \& Malec- 
Milewska, 2014).

Dr. Sitanala is a public service agency belonging to the Ministry of Health in the Tangerang area where one of the services is surgery using anesthesia. There were 101 patients of surgery at dr. SitanalaHospital in the last 3 months from December 2018-February 2019.

The Surgical Room Installation of the dr. Sitanala Hospital provides 2 pieces of $38^{\circ} \mathrm{C}$ electric warming blankets but due to the limited number of tools, not all patients undergoing surgery use a heating blanket but are provided with regular blankets. The effect of giving with an ordinary blanket has not shown maximum results, in fact shivering reactions are still common in postoperative patients and there are also no studies that show the effect of giving $38^{\circ} \mathrm{C}$ electric warming blankets on reducing the incidence of shivering in postoperative patients.

\section{METHODOLOGY}

This type of research was a quasi-experimental research type with a pre-test post-test design with control group. The research was conducted at the Surgical Installation of dr. Sitanala Tangerang Hospital. The research was conducted in June 2019.

The sample of this study were all postoperative patients in the Surgical Installation of dr. SitanalaTangerang Hospital for the period of June 2019. The sampling technique in this study was Total Sampling. The criteria for the characteristics of the sample that could be included or were eligible for research, namely: adult age ( $>18$ yearsold), willing to be a respondent as evidenced by filling in informed consent, postoperative patient with full awareness (composmentis), can communicate well (using Indonesian), duration of operation was about 1-2 hours.

The instrument in this study was an observation sheet consisting of two parts, the first part was about the patient's personal data and the second part was about the data on the incidence of shivering with the provision of an electric warm blanket with a temperature of $3800 \mathrm{C}$ which was given since the beginning of the patient's handover at the dr. Sitanala Tangerang Hospital until the end of surgery / postoperative. The other tools were a thick cloth blanket and the Warm Touch electric warm blanket, had been tested for the function of the tool or calibration to ensure that the tool was functioning properly on $03 / 12 / 2018$ with a validity period until 12/3/2019, a timer/ hour, stationary and data processing tools such as calculators and computers. Data analysis was carried out in univariate and bivariate ways using the Wilcoxon test.

\section{RESULTS AND DISCUSSION}

Univariate Analysis

Table 1: The Description of postoperative patients' age in the surgical installation of dr. SitanalaTangerang Hospital for the period of June 2019

\begin{tabular}{|l|c|c|c|c|c|}
\hline $\begin{array}{l}\text { Group of } \\
\text { Blanket }\end{array}$ & Mean & Median & SD & Min-Max & $95 \%$ CI \\
\hline Electric & 41,47 & 42 & 6,70 & $25-53$ & $37,76-45,17$ \\
\hline Regular & 37 & 37 & 10,75 & $22-58$ & $31,26-43,15$ \\
\hline
\end{tabular}

From the results of the analysis of age characteristics in the treatment group (electric blanket), it was found that 15 postoperative patients had a mean age of 37 with a median of 37 years old with a standard deviation of 10.75. The youngest was 25 years old and the oldest was 53 years old. From the results of the analysis of age with a median of 42 years old and a standard deviation of 6.70, it was found that the youngest age was 22 years old and the oldest was 58 years old. Age characteristics in the control group (regular blanket) had 15 postoperative patients with the average age of 41.47 .

Table2. The description of postoperative patients'gender in the surgical installation of dr. SitanalaTangerang Hospital for the period of June 2019

\begin{tabular}{|l|c|c|c|c|}
\hline \multirow{2}{*}{ Gender } & \multicolumn{2}{|c|}{ Group of Electric Blanket } & \multicolumn{2}{c|}{ Group of Regular Blanket } \\
\cline { 2 - 5 } & $\mathrm{f}$ & $\%$ & $\mathrm{f}$ & $\%$ \\
\hline Male & 6 & 40 & 7 & 46,7 \\
\hline Female & 9 & 60 & 8 & 53,3 \\
\hline Total & 15 & 100 & 15 & 100 \\
\hline
\end{tabular}

According to the table 2 above it was found that 15 post operative patients, the most of them who got electric blanketswere female by $9(60 \%)$. On the group of regular blankets, the mostpostoperative patients were female by 8 $(53,3 \%)$. 
Table 3.The description of shivering incidence of postoperative patients provided electric blankets in the surgical installation of dr. Sitanala Tangerang Hospital for the period of June 2019

\begin{tabular}{|l|c|c|c|c|}
\hline \multirow{2}{*}{ Grade of Shivering } & \multicolumn{2}{|c|}{ Before(Pretest) } & \multicolumn{2}{c|}{ After(Postest) } \\
\cline { 2 - 5 } & $\mathrm{f}$ & $\%$ & $\mathrm{f}$ & $\%$ \\
\hline Grade 0 & - & - & 6 & 40 \\
\hline Grade 1 & 1 & 6.7 & 5 & 33.3 \\
\hline Grade 2 & 5 & 33.3 & 4 & 26.7 \\
\hline Grade 3 & 7 & 46.7 & - & - \\
\hline Grade 4 & 2 & 13.3 & - & - \\
\hline Total & 15 & 100 & 15 & 100 \\
\hline
\end{tabular}

From the table 3, it was found that from 15 postoperative patients before they were provided electric blankets, almost half of them underwent grade 3 shivering incidence by $7(46,7 \%)$ (it had moderate muscular activity in more than one muscle group, but it had no visivble shivering throughout the body). After providing the warming electric blankets, almost half of the postoperative patients namely $6(40 \%)$ didn't undergo shivering (grade 0 ).

Tabel 4: Description of shivering incidence of postoperative respondents provided regular thick blankets in the surgical installation of dr. Sitanala Tangerang Hospital for the period of June 2019

\begin{tabular}{|l|c|c|c|c|}
\hline \multirow{2}{*}{ Grade of Shivering } & \multicolumn{2}{|c|}{ Before (Pretest) } & \multicolumn{2}{c|}{ After (Postest) } \\
\cline { 2 - 5 } & $\mathrm{f}$ & $\%$ & $\mathrm{f}$ & $\%$ \\
\hline Grade 0 & - & - & 1 & 6.7 \\
\hline Grade 1 & 2 & 13.3 & 3 & 20 \\
\hline Grade 2 & 6 & 40 & 6 & 40 \\
\hline Grade 3 & 4 & 26.7 & 5 & 33.3 \\
\hline Grade 4 & 3 & 20 & - & - \\
\hline Total & 15 & 100 & 15 & 100 \\
\hline
\end{tabular}

From the table4, it was found that among 15 postoperative patients before providing regular blankets, almost half of them namely $6(40 \%)$ underwent shivering grade 2 (it had muscular activity in one muscle group) and almost half of them namely 4 $(26,7 \%)$ underwnet shivering grade 3 (it had moderate muscular activity in more than one muscle group, but it didn't seem shivering throughout the body). After the respondents were provided regular warming blankets, amost half of them namely $6(40 \%)$ underwents shivering grade 2 (it had muscular activity in one muscle group).

\section{Bivariate Analysis}

The effectiveness analysis in providing thick blankets and $380 \mathrm{C}$ electric blankets with reducing shivering incidence on postoperative patients in Surgery Installation dr. Sitanala Tangerang Hospital was conducted using a paired t-test (dependent) where the analytical data normality test was conducted first using shapirowilk test (the amount of data $<60$

namely 15 for each group). The normality data hypothesis are:

$$
\begin{aligned}
& \mathrm{H} 0=\text { Normally Distributed Data } \\
& \mathrm{H} 1=\text { Abnormally Distributed Data }
\end{aligned}
$$

Here are the results of normality shivering grade data before and after electric blankets and warming Blanket group:

Table 5. Normality data of shivering grade before and after providing electric blankets and warrming

\begin{tabular}{|c|c|c|c|c|c|}
\hline \multirow[t]{2}{*}{ Group } & \multirow{2}{*}{$\begin{array}{l}\text { Grade of } \\
\text { Shivering }\end{array}$} & \multicolumn{3}{|c|}{ Shapiro Wilk Test } & \multirow{2}{*}{ Conclusion } \\
\hline & & Statistic & $\mathrm{df}$ & P value & \\
\hline \multirow[t]{2}{*}{ Electric blankets } & Before & 0,881 & 15 & 0,049 & $\begin{array}{c}\text { Abnormally } \\
\text { Distributed } \\
\text { Data }\end{array}$ \\
\hline & After & 0,799 & 15 & 0,004 & $\begin{array}{c}\text { Abnormally } \\
\text { Distributed } \\
\text { Data }\end{array}$ \\
\hline \multirow[t]{2}{*}{ Regular Balnkets } & Before & 0,882 & 15 & 0,041 & $\begin{array}{c}\text { Abnormally } \\
\text { Distributed } \\
\text { Data }\end{array}$ \\
\hline & After & 0,862 & 15 & 0,026 & $\begin{array}{c}\text { Abnormally } \\
\text { Distributed } \\
\text { Data }\end{array}$ \\
\hline
\end{tabular}
blankets

With alpha $5 \%$, this could be concluded that it had abnormally distributed data. The bivariate test was using Wilcoxontest because the data was distributed abnormally. 
Table 6: The effect of providing electric blankets on shivering incidence in postoperative patients in surgery installation of $d r$. Sitanala Tangerang Hospital for the period of June 2019

\begin{tabular}{|l|c|c|c|c|c|c|c|}
\hline $\begin{array}{l}\text { Grade of } \\
\text { Shivering }\end{array}$ & $\mathrm{n}$ & Mean & $\begin{array}{c}\text { Negative } \\
\text { ranks }\end{array}$ & $\begin{array}{c}\text { Postive } \\
\text { ranks }\end{array}$ & Ties & $\mathrm{Z}$ count & $P$ value \\
\cline { 1 - 6 } & 15 & 2.67 & 14 & 0 & 1 & -3.402 & 0.001 \\
\hline After & 15 & 0.87 & & & & \\
\hline
\end{tabular}

From the analysis results, it was found that the average grade of shivering before providing electric blankets was 2.67 and after providing was 0.87 . There were 14 postoperative patients before treatment had shivering grade $<$ after treatment (negative ranks), and 1 postoperative patient who underwent shivering before and after providing electric blankets was the same (ties). The result of Wilcoxon test was Pvalue $(0,001)$ $<\alpha(0,05)$ thenHo was rejected. It means there was an effect of providing electric blankets on shivering incidence in postoperative patients in Surgery Installation of dr. Sitanala Tangerang Hospital.

Table 7. The effect of providing regular thick blankets on shivering incidence in postoperative patients in surgery installation of dr. Sitanala Tangerang Hospital for the period of June 2019

\begin{tabular}{|l|c|c|c|c|c|c|c|}
\hline $\begin{array}{l}\text { Grade } \\
\text { of Shivering }\end{array}$ & $\mathrm{n}$ & Mean & $\begin{array}{c}\text { Negative } \\
\text { ranks }\end{array}$ & $\begin{array}{c}\text { Postive } \\
\text { ranks }\end{array}$ & Ties & Z count & $P$ value \\
\cline { 1 - 6 } Before & 15 & 2,53 & 8 & 0 & 7 & -2.828 & 0,005 \\
\cline { 1 - 6 } & 15 & 2 & & & & & \\
\hline
\end{tabular}

From the analysis above, it was found that the average grade of shivering before (pretest) providing regular thick blankets was 2.53 and after treatment (postest) was 2,00 . There were 8 postoperative patients before treatment had shivering grade $<$ after treatment (negative ranks), and 7 postoperative patient who underwent shivering before and after providing electric blankets was the same (ties). The result of Wilcoxon test was $\mathrm{P}$ value $(0,005)<\alpha(0,05)$ thenHo was rejected. It means there was an effect of providing regular thick blankets on shivering incidence in postoperative patients in Surgery Installation of dr. Sitanala Tangerang Hospital.

Based on table 1 showed that among 15 postoperative patients, the average age was 37 years old with the youngest was 25 years old and the oldest was 53 years
old.This results is aligned with the research of Oktavian et al (2014) entitled Perbandingan Pemberian Ondansetron $8 \mathrm{mg}$ dengan Tramadol $1 \mathrm{mg} / \mathrm{kgbb}$ Intravena Untuk Mencegah Menggigil Pascaanastesi Umum pada Operasi Mastektomi Radikal atau Modifikasiwith the results of postoperative patients' average age was 46.7 years old. The research of Setiyanti [Setiyanti, 2016] in 2016 stated that based on the age of postoperative hypothermic patients in Salatiga Regional Hospital, in the control group or patients without aluminum foil blankets, the most were between the ages of 21-40 years old, namely 13 people $(81.3 \%)$ while in the treatment group the most were 21 40 years old as many as 6 people $(37.5 \%)$.

Long life span is the single most important cause of the increasing number of critically ill patients with multiple and acute illnesses. The older a person is, the physiological changes will be due to the aging process. These changes will have an impact on one's health. This condition usually causes hospitalization where operative management can be performed (Hudak \& Gallo, 1986).

Age is one of the factors that affect body temperature. The temperature between infants, children, adults, and the elderly will be very different because of the differences in the maturity function of the hypothalamus. Body temperature regulation is not stable until puberty of children. The normal temperature range decreases gradually until the person approaches old age (elderly). The average body temperature of the elderly is around $36^{\circ} \mathrm{C}$. Early adults have a wider body temperature interval than the elderly. The deterioration of control mechanisms, especially in vasomotor control (vasoconstriction and vasodilation control), decreased amount of subcutaneous tissue, decreased sweat gland activity and decreased metabolism make the elderly more sensitive to extreme environmental temperatures. Individual differences of $0.25^{\circ} \mathrm{C}$ to $0.55^{\circ} \mathrm{C}$ are normal (Potter, \& Perry 2005).

The researchers argue that elderly patients (elderly), including the extreme age group, are at high risk for hypothermia in the perioperative period. General anesthesia performed on elderly patients can cause a higher degree of shift in the threshold for thermoregulation than in younger patients.

Based on table 2, it is known that of the 15 postoperative respondents who were given electric blankets, most of them were female, namely $9(60 \%)$, while the regular blanket group was mostly female, namely $8(53.3 \%)$. These results are in line with Islami's (Islami \& Budiono, 2012) research in 2012 entitled 
Pengaruh Penggunaan Ketaminterhadap Kejadian Menggigil Pasca Anestesi Umum, which stated that the majority of postoperative patients both in the ketamine and saline groups were women, as many as 13 (54.17\%). Setiyanti's (Setiyanti, 2016) research in 2016 on postoperative hypothermic patients in Salatiga Hospital, namely in the control group, most of the women were 13 people $(81.3 \%)$ and the treatment group was mostly female patients as many as 10 people $(62.5 \%)$.

Men and women have differences in the consistency of body temperature. In general, women have greater body temperature fluctuations than men. This happens because of the influence of hormonal production, namely the hormone progesterone. If the progesterone hormone is low, then the body temperature will decrease a few degrees below normal limits (Kozier et al., 2010 and Potter \& Perry 2005).

The majority of respondents were female because indeed the majority of the procedure (surgery) was the type of postoperative sectio secaria. Sectio secaria is only performed on pregnant women with complications if they are born normally, spinal anesthesia is performed.

Based on table 3 and table 4, it showed that of the 15 postoperative patients before being provided electric blanket, almost half of them, namely $7(46.7 \%)$ underwentgrade 3 shivering incidence (moderate muscular activity in more than one muscle group, but no shivering throughout the body). Meanwhile, of 15 postoperative patients before being provided a regular thick blanket, almost half of them,

namely 6 (40\%) underwent grade 2 shivering (muscular activity in only one muscle group) and nearly half of them underwent grade 3 shivering (moderate muscular activity. in more than one muscle group, but no visible shivering throughout the body) namely 4 $(26.7 \%)$.This result is in line with the research of Nayoko (Nayoko, 2016) in 2016 which stated that most of postoperative SC patients in the Surgery Room in dr. M. Soewandhie Surabaya underwent shivering degrees 1-4, while the highest degree of shivering was on a score of 3 at $38.10 \%$.

Patients who undergo surgery are at risk of developing hypothermia. Postoperative hypothermia can cause cardiac dysrhythmias, prolong surgical wound healing, shivering, shock and decreased patient comfort. Shivering is a condition characterized by increased muscular activity that often occurs after anesthesia (Abdelrahman, 2012). This process is a normal response to thermoregulation that occurs to hypothermia, but this process can also be caused by pain stimuli and also certain anesthetic drugs.

The combination of anesthesia and surgery can cause disruption of the function of body temperature regulation which will cause a decrease in core temperature, causing hypothermia (Fauzi, 2014 \& Nicholson, 2013).

Shivering is an uncomfortable response for the patient and will pose an unfavorable risk to the patient because it is associated with sympathetic/ adrenergic activation such as increased metabolic processes, increased oxygen consumption by 4-6 times, increased carbondioxide production and aggravation of pain postoperative. Increased levels of catecholamines in the blood will also increase the risk of cardiovascular complications (Fatoni, Isngadi, \& Jaya et al., 2014).

The researchers think the decrease in core body temperature found in this study is due to general anesthesia action which causes vasodilation as well as a decrease in the threshold of shivering so that the patient becomes hypothermic. A decrease in core body temperature will stimulate shivering, which is one of the body's mechanisms to increase heat production and also vasoconstriction to reduce heat loss.

Based on table 4, showed that of 15 postoperative patients after being provided an electric warming blanket, almost half of them, namely $6(40 \%)$ did not undergo shivering (grade 0 ).

Meanwhile, of the 15 postoperative patients after being provided a regular warming blanket, almost half of them, namely $6(40 \%)$ underwent grade 2 shivering (muscular activity in only one muscle group).In line with the research of Suagianto \& Juanita (Sugianto and Juanita, 2013) in 2013 after the treatment (postest), it showed that in the group provided regular blankets most of the respondents were shivering in more than one muscle group (shivering grade 4), namely 13 people $(86.67 \%)$ in the 1 st minute. and the 10th minute, while in the group that was provided electric blanket $380 \mathrm{C}$ the majority of respondents, namely 15 people $(100 \%)$ underwent grade 1 shivering at the first minute and 13 people had grade 1 shivering at the tenth minute after surgery

Efforts to overcome the shivering effects of postoperative hypothermia, by means of pharmacotherapy include drugs, both opioid and nonopioid which had been tested to treat postoperative hypothermia. Giving drugs certainly causes side effects in the form of nausea, vomiting and respiratory depression (Arifin \& Sanjaya, 2012). Nonpharmacotherapy includes various mechanical 
interventions such as warm intravenous fluids, heating lamps, warming blankets, heating mattresses, warm humidifiers and increased room temperature, pressurized heating systems, electric mattresses and blankets, and water mattress and covers (Horosz \& Malec-Milewska, 2014).

In the treatment group with an electric warming blanket, the grade of shivering is still normal, because the process of losing body heat occurs in the first hour of surgery and causes hypothermia by warming the patient during surgery which can increase body temperature. The process of shivering that occurs after surgery will last for more than 15 minutes after giving anesthesia (Suindrayasa, 2017).

There is a difference in the incidence of shivering after providing a regular blanket and an electric warming blanket because the use of a thick blanket does not occur in the delivery of heat from the blanket to the body. Heat production only occurs in the body, the blanket only prevents the release of heat that has been produced by the body and prevents the body from being exposed to cold temperatures again. This is consistent with the statement from Cuming and Janel cited by Kesuma and Wijaya [10] in 2013 which explains there are three reasons why thick blankets are not optimal in handling hypothermic patients, namely: (1) Thick blankets only wrap or protect patients from more heat loss. severe; (2) The heating process only relies on heat production from within the body, blankets only help prevent the release of heat that has been produced in the body; (3) There is no transfer of heat from the thick blanket into the patient's body. It is different with the intervention using warmer brankets, in this intervention the production of heat is not only from within the body but the delivery of heat from outside also accelerates the increase in temperature in the body. In accordance with Gabriel's theory cited by Kesuma and Wijaya (Kesuma \& Wijaya, 2013) in 2013, it is explained that radiation from the use of a warming blanket warmer can transfer heat to the objects itshines, including the human body, so that in heating lamp intervention, besides heat production from the body, heat is also transferred through radiation. from outside the body so as to reach the entire body temperature increase will occur faster. This is what causes the use of thick blankets in overcoming hypothermia that occurs in post-caesarean section patients. Therefore, blanket warmer intervention is recommended in an effort to overcome hypothermia that occurs in patients with surgery, especially cesarean section.

In this study, the reduction in the incidence of shivering was more in the group provided electric blankets. The researchers assume that the heating action that is carried out by providing an electric blanket is by means of active external warming, this action can increase the average body temperature by increasing the energy content in the peripheral compartments of the body. So that body heat does not come out to the outside environment. Containing polyester fiber and coated with microfilament which is equipped with temperature control, this method is an efficient and fast way to produce temperature regulation in patients and regulation of body temperature after surgery.

Based on table 6 dan table 7, that both electric blankets and warming blankets had an effect on the incidence of shivering in postoperative patients in the Surgery Installation of dr. Sitanala tangerang Hospital. Where the results of the Wilcoxon test on the provision body heat.

The electric warming blanket is an efficient and fast way to provide patient temperature regulation and postoperative temperature regulation. Hughes said that patients provided a warming blanket during induction of anesthesia reduced postoperative shivering by $63 \%$. Pathophysiologically, a warming blanket will be able to increase core body temperature by conduction through the peripheral blood flow to the core part of the body (Suindrayasa, 2017).

Containing polyester fiber and coated with microfilament which is equipped with temperature control, this method is an efficient and fast way to produce temperature regulation in the patient and regulation of body temperature after surgery, resulting in reduced incidence of shivering. In addition, the electric warm blanket (warm blanket) has a temperature setting, so that it can be adjusted to the patient's needs, postoperative patients must be kept as warm as possible to minimize heat loss without causing vasodilation which can cause more bleeding (Black \& Hawks, 2014).

The heat transfer that occurs in the use of the Warm Blanket goes through several processes, including conduction, namely the process of transferring heat directly between two related solid materials, heat will spread from a higher temperature to a lower temperature, in this study from the temperature in the Warm Blanket. 380C to skin surface. Convection is the process of heat propagation that occurs through liquid or gas media. The amount of convection depends on the area of contact and the difference in media temperature.

This process is influenced by the temperature on the skin surface, air temperature, skin surface area, and the velocity of air movement around the skin. The heat loss 
that occurs in this study is that almost the entire patient's body is covered with Warm Blanket except for the face, heat loss through convection can be minimized so that there is a decrease in the incidence of shivering.

The researchers assume that the provision of an external active heating method in the form of providing an electric warm blanket with a temperature of $38^{\circ} \mathrm{C}$ during surgery with the hope that it will conduct through the blood flow from the periphery to the whole body and the release of heat from the body is inhibited. Postoperativethe temperature is within normal limits, by providing an electric warm blanket can increase the average body temperature by increasing the energy content in the peripheral compartments of the body besides that heat loss through convection can be minimized so that there is a decrease in the incidence of shivering.

\section{CONCLUSION}

It was identified from 15 postoperative patients before being provided an electric blanket, almost half of them underwent grade 3 shivering by $46.7 \%$, while in patients who were provided regular blankets almost half of them underwent grade 2 shivering by $40 \%$ and nearly half of themunderwent grade 3 shivering by $26.7 \%$. It was identified from 15 postoperative patients after being provided an electric warming blanket, almost half of them did not experience shivering (grade 0 ) by $40 \%$, while in patients who were provided regular blankets almost half of them underwent shivering grade 2 by $40 \%$.Electric warming blankets or warm blankets usually have an effect on the shivering incidencein postoperative patients in the Surgery Installation of dr. Sitanala Tangerang Hospital. Where the results of the

Wilcoxon test on the provision of electric blankets obtained $\mathrm{P}$ value $(0.001)<(0.05)$ and on the provision of ordinary blankets obtained $\mathrm{P}$ value $(0.005)<(0.05)$. However, electric blankets are more effective than regular warming blankets.

\section{ACKNOWLEDGMENTS}

We would like to thank the chairwoman of STIKes Widya Dharma Husada for sharing her pearls of wisdom with us during this research, and we also thank the reviewers for their constructive comments and suggestions.

\section{REFERENCE}

Abdelrahman, R. S. (2012). Prevention of shivering during regional anaesthesia: Comparison of Midazolam, Midazolam plus ketamine, Tramadol, and Tramadol plus Ketamine. Life sci J, 9(2), 132-9..

Arifin, J., \& Sanjaya, Y. A. (2012). PERBANDINGAN EFEKTIVITAS ONDANSETRON DAN TRAMADOL INTRAVENA DALAM MENCEGAH MENGGIGIL PASCA ANESTESI UMUM. Medica Hospitalia: Journal of Clinical Medicine, 1(1).

Black, J. M., \& Hawks, J. H. (2014). Keperawatan Medikal Bedah; Manajemen klinis untuk hasil yang diharapkan.

Fatoni, A. Z., Isngadi, I., \& Jaya, W. (2014). Perbandingan efek pemberian ondansetron dan petidin intravena untuk mencegah menggigil pasca anestesi umum. JAI (Jurnal Anestesiologi Indonesia), 6(2).

Fauzi, A. (2014). Gambaran Kejadian Menggigilpada Pasiendengan Tindakan Operasi yang Menggunakan Anastesi Spinal di RSUD Karawang. Jurnal Kebidanan; 8(2) 86-92.

Guyton, A.C., and Hall, J. E. 2014. Buku Ajar Fisiologi Kedokteran. Edisi 18. Penterjemah: Irawati, Ramadani D, Indriyani F. Jakarta: Elsevier.

Horosz, B., \& Malec-Milewska, M. (2014). Methods to prevent intraoperative hypothermia. Anaesthesiology intensive therapy, 46(2), 96-100.

Hudak, C. M., \& Gallo, B. M. (1986). Critical care nursing: A holistic approach. Lippincott Williams $\&$ Wilkins.

Islami, R. H., \& Budiono, U. (2012). Pengaruh penggunaan ketamin terhadap kejadian menggigil pasca anestesi umum (Doctoral dissertation, Fakultas Kedokteran).

Kesuma and Wijaya. 2013. Perbedaan Efektivitas Pemberian Selimut Tebaldan Lampu Penghangatpada Pasien Pasca Bedah Sectio Caesarea yang Mengalami Hipotermi di Ruang Pemulihan OK RSUD Sanjiwangi Gianyar. Jurnal Kedokteran. Bali: Universitas Udayana

Koeshardiandi, M. (2011). Efektifitas Ketamin Dosis 0, $25 \mathrm{mg} / \mathrm{kg}$ Berat Badan Intravena sebagai Terapi Menggigil Selama Anestesi Spinal padaPembedahan Sectio Caesaria. Journal Anestheia of Emergency, 2(3).

Kozier, B., Erb, G., Berman, A., \& Snyder, S. J. (2010). Fundamental Keperawatan Konsep, Proses, \& Praktik. Jakarta: EGC. 
Nayoko, N. (2017). PERB ANDINGAN EFEKTIFITAS PEMBERIAN CAIRAN INFUS H A NGAT TERHA D A P KEJADIAN MENGGIGIL PADA PASIEN SECTIO CAESARIA DI KAMAR OPERASI. Jurnal Keperawatan Muhammadiyah, 1(1).

Nicholson, M. (2013). A comparison of warming interventions on the temperatures of inpatients undergoing colorectal surgery. AORN journal, 97(3), 310-322.

Potter, P. A., \& Perry, A. G. (2005). Fundamental Keperawatan, Konsep, Proses dan Praktik. Jakarta: Egc.

Setiyanti, W. (2016). Efektifitas Selimut Alumunium Foil Terhadap Kejadian Hipotermi pada Pasien
Post Operasi RSUD Kota Salatiga. Jurnal Publikasi Ilmiah. Surakarta: S1 Keperawatan Stikes Kusuma Husada Surakarta.

Sugianto and Juanita. 2013. Pengaruh Pemberian Selimut Elektrik Suhu 380C Selama TUR-P dengan SAB Terhadap Kejadian Menggil Pasca Bedah di RS Aisyoyah Bojonegoro, Jurnal Surya Vol. 02, No. XV, Agustus 2013. Retrieved from https://stikesmuhla.ac.id/wp-content/uploads//4044-Farida-Juanita.pdf on March $20^{\text {th }} 2019$.

Suindrayasa, I.M. 2017. Efektifitas Penggunaan Selimut Hangat Terhadap Perubahan Suhu Pada Pasien Hipotermia Post Operasi di Ruang ICU RSUD Buleleng. ArtikelIlmiah. Program Studi Sarjana Keperawatandan Pofesi Ners. Bali :Universitas Udayana. 